OPEN

SUBJECT AREAS:

PALAEOECOLOGY

URBAN ECOLOGY

Received

27 September 2013

Accepted

2 December 2013

Published

18 December 2013

Correspondence and requests for materials should be addressed to D.K. (david. kaniewski@univ-tlse3.

\title{
Early urban impact on Mediterranean coastal environments
}

\author{
David Kaniewski ${ }^{1,2,3}$, Elise Van Campo ${ }^{1,2}$, Christophe Morhange ${ }^{3,4}$, Joël Guiot ${ }^{4}$, Dov Zviely ${ }^{5}$, Idan Shaked ${ }^{5}$, \\ Thierry Otto ${ }^{1,2} \&$ Michal Artzy,6
}

\begin{abstract}
'Université Paul Sabatier-Toulouse 3, EcoLab (Laboratoire d'Ecologie Fonctionnelle et Environnement), Bâtiment 4R 1, 118 Route de Narbonne, 31062 Toulouse cedex 9, France, ${ }^{2}$ CNRS, Ecolab (Laboratoire d'Ecologie Fonctionnelle et Environnement), 31062 Toulouse cedex 9, France, ${ }^{3}$ Institut Universitaire de France, 103 boulevard Saint Michel, 75005 Paris, France, ${ }^{4}$ Aix-Marseille University, CNRS, UM 34, Europôle de I'Arbois BP80, F-13545 Aix-en-Provence, France, ${ }^{5}$ Leon Recanati Institute for Maritime Studies, University of Haifa, Mount Carmel, Haifa 3190501 , Israel, ${ }^{6}$ Hatter Laboratory, University of Haifa, Mount Carmel, Haifa 3190501, Israel.
\end{abstract}

A common belief is that, unlike today, ancient urban areas developed in a sustainable way within the environmental limits of local natural resources and the ecosystem's capacity to respond. This long-held paradigm is based on a weak knowledge of the processes underpinning the emergence of urban life and the rise of an urban-adapted environment in and beyond city boundaries. Here, we report a 6000-year record of environmental changes around the port city of Akko (Acre), Israel, to analyse ecological processes and patterns stemming from the emergence and growth of urban life. We show that early urban development deeply transformed pre-existing ecosystems, swiftly leading to an urban environment already governed by its own ecological rules and this, since the emergence of the cities.

\begin{abstract}
- he question of whether or not the emergence of cities ${ }^{1,2} \sim 6000$ years ago and the subsequent early urban growth in Western Asia ${ }^{3-7}$ deeply impacted natural environments and pushed them towards irreversible changes, has gained new interest because of the recent reassessment of ecological interactions caused by and taking place in urban environments ${ }^{8-13}$. Urban developments have been emergent phenomena of local-scale, evolving as the outcome of dynamic interactions among biophysical, human and socio-economic forces in which each component contributes to but does not control the form and behaviour of the whole ${ }^{14,15}$. Since the emergence of cities, the growing urban context has gradually shaped the socio-ecological interactions that have been both drivers and responders to long-term environmental changes ${ }^{11,14}$. Urbanization is one of the dominant demographic trends of our time, and more than $50 \%$ of humans will be concentrated in cities in 30 years time, as a result of increasing human population and migration from rural to urban areas ${ }^{11,13}$. Urban growth involves one of the most extreme forms of ecological stress and land alteration ${ }^{10}$. Humanity has long experienced a shift towards urban living ${ }^{2-6}$, but it is still equivocal whether the process of economic development was based upon the realities of the available ecological capital, or if such changes acted like a trigger to a profound environmental degradation. As new urban restoration targets focus on the temporal and spatial dimensions of the ecological history ${ }^{16}$, a thorough knowledge of the early interactions between natural communities and human activities in and around an emerging city, may help recovering the original patterning.

Here, the emergence of an urban environment as a unique setting was analyzed through the investigation of patterns of pressure and selection on ecosystems on the coastal strip of Israel, the ancient and present economic heart ${ }^{17}$ of a country where $91.9 \%$ of the population live in urban areas ${ }^{18}$. With high density urban development and relatively scarce land resources, the coast and seashore are vital open-spaces. The port city of Akko (Acre), a UNESCO world heritage site, is one of the oldest continuously inhabited places and a strategic link to the Levant (Supplementary Fig. S1a-b), leading eastward to the Jordan Valley and further to Transjordan ${ }^{19-22}$. Except for short periods, Akko was an important Eastern Mediterranean administrative and trading center from $\sim 4000$ calendar years before the present (BP) to the Ottoman period. The ecological impact of the spurt of urbanization on and beyond the most ancient site, located on a tell at a short distance from modern Akko, was reconstructed from a continuous and well-dated (Table 1) 6000-year record of ecosystem dynamics (Fig. 1a).
\end{abstract}

\section{Results}

An outstanding feature of the recorded urban environmental history of Akko is that the area rapidly shifted from a densely forested landscape to a shrub-steppe (Fig. 1a-b) between $\sim 4000$ and 3300 calibrated years before the 
Table 1 | Details of the radiocarbon age determinations for the Akko core. The radiocarbon ages are expressed in calibrated year BP at 68$95 \%$ of probability

\begin{tabular}{|c|c|c|c|c|c|}
\hline $\begin{array}{l}\text { Akko core } \\
\text { Code }\end{array}$ & Depth cm & ${ }^{14} \mathrm{C}$ yr BP & \multicolumn{2}{|c|}{ Calibrated dates BP } & $\begin{array}{l}\text { Intercepts } \\
\text { Cal yr BP }\end{array}$ \\
\hline BETA-337808 & 80 & $190 \pm 30$ & $190-160$ & $225-140$ & 170 \\
\hline BETA-347581 & 133 & $2770 \pm 30$ & $2890-2840$ & $2950-2790$ & 2860 \\
\hline BETA-347582 & 173 & $4330 \pm 30$ & $4890-4850$ & $4970-4840$ & 4860 \\
\hline BETA-337810 & 215 & $5200 \pm 30$ & $5950-5920$ & $6000-5910$ & 5930 \\
\hline
\end{tabular}

present (cal yr BP). The regional climatic trends (Fig. 1c-d) do not support climate as a primary cause for this shift, since no decreasing precipitation (Fig. 1c), consistent with a forest-steppe shift, is observed for this period. Higher amounts of precipitation at Akko since $\sim 4000 \mathrm{cal}$ yr BP are also recorded in the Eastern Mediterranean by low $\delta^{18} \mathrm{O}$ values on Ashdod Coast ${ }^{23,24}$ and Soreq $\mathrm{Cave}^{25}$. Higher precipitation in the Dead $\mathrm{Sea}^{26}$ and in the Sea of Galilee $^{27}$, as well as increased Nile floods ${ }^{28}$ and a wet phase in coastal Syria $^{29}$ all suggest that the $4000-3300$ cal yr BP period is inconsistent with climate pressure as a forcing factor behind the forest-steppe shift. Only a background of changes in coastal morphology due to relative sea level changes ${ }^{30,31}$ (Supplementary Fig. S1a), which also controlled the evolution of the coastal ecosystems in and around Akko (Fig. 1a), are recorded between 4000 and $3300 \mathrm{cal} \mathrm{yr} \mathrm{BP.}$ Although the coastal mobility of the Haifa Bay was one of the forcing factors that impacted upon ecosystem dynamics since $8500 \mathrm{cal} \mathrm{yr}$ $\mathrm{BP}^{32}$, the final stage of ecological erosion at the site, a permanent open shrub-steppe (Supplementary Fig. S2), was only reached after the emergence of the city (Fig. 1a). The first interventions, substitutions and transformations of the pristine Mediterranean forest promptly followed the occurrence of the earliest urban structures, dated from the Middle Bronze Age IIA culture ( $4000 \mathrm{BP})$. The local urbanization occurred at the termination of the $4200 \mathrm{cal} \mathrm{yr} \mathrm{BP}$ drought event ${ }^{33-35}$ (Fig. 1c), paralleling the dense occupation phase that appeared along the southern Levantine coastal area (Fig. 2). The city rapidly developed with ramparts, buildings and industrial areas ${ }^{20-22}$ (Supplementary Fig. S1b). The anchorage, in connection with the Na'aman River fluvial system, was the focus of the economy and trade, and the main driver behind urban population growth. The spatial concentration of agricultural, industrial and commercial activities led to increased demands on local ecosystems (Fig. 1a), and to an encroachment on and a loss of natural biotopes in and around the tell. Fragmented proto-urban ecosystems only persisted as small patches within a matrix of urban and agricultural expansion (Supplementary Fig. S3a-b), or even disappeared. This humaninduced ecological imbalance has prevailed throughout the last $\sim 4000$ years, as the coastal vegetation became dominated by a dry and urban-adapted woodland (Supplementary Fig. S3c) in association with a shrub-steppe, which became prevalent during two periods, 1670 to $1060 \mathrm{cal} \mathrm{yr} \mathrm{BP}$ and 430 to $100 \mathrm{cal} \mathrm{yr} \mathrm{BP.}$

During the first millennium of human occupation, a sharp decrease in agricultural productivity at 3250-3200 cal yr BP (Fig. 1a) is associated with a weakening of the economy and reduction in habitation at Akko. The $3200 \mathrm{cal}$ yr BP drought event ${ }^{36,37}$ had affected most of the Eastern Mediterranean and adjacent regions ${ }^{26-29}$. Even if the patterns of sprawl were primarily controlled by humans since their settlement at Akko, at the end of the Late Bronze Age $(\sim 3200 \mathrm{BP})$, the cumulative influence of reduced precipitation (Fig. 1c), coastal progradation ${ }^{38}$ due to slower relative sea-level rise ${ }^{39}$, and the continuous Nile-derived sand deposition in Haifa Bay area with the silting up of the Na'aman River mouth ${ }^{38}$, generated a drier coastal area and the subsequent development of a dry steppe at $\sim 3160 \mathrm{cal}$ yr BP. These processes have constrained the rate of urban and economic development, stressing the limiting role of coastal changes (progradation, silting up of the river mouth) and water availability (surface versus groundwater; depending on functional pits) for urban growth. Although the $3200 \mathrm{cal}$ yr BP event locally ended at $\sim 2900-2800$ cal yr BP, the re-emergence of extensive habitation pattern and trade networks only occurred after $\sim 2650 \mathrm{BP}$, during the Phoenician/Persian and Early Hellenistic periods, and is clearly marked in the environment (Fig. 1a).

A second sharp decrease in agricultural productivity was recorded since $\sim 650 \mathrm{cal} \mathrm{yr} \mathrm{BP}$, at the end of the Crusader period-onset of the Mamluk-Ottoman era. Following the fall of the Crusaders, the area was left untilled and under urbanized for a long time. Akko was replaced by Safed as the administrative city of the Mamluks. During the Ottoman period, Akko was described by pilgrims and merchants who visited it in the $16^{\text {th }}$ and $17^{\text {th }}$ centuries as a deserted ghost town, with some structures from the Crusader period still standing, some jutting out of the earth, and others buried. Regardless of the causes behind the decay of Akko since $650 \mathrm{BP}$, the lack of resilience of coastal ecosystems following the abandonment of the town may result from 3500 years of continuous human pressure, leading to an ecological erosion marked by non-regenerating stands of forested communities. The dry conditions of the Little Ice Age are only recorded after $\sim 500 \mathrm{cal}$ yr BP in the Levant ${ }^{23,24}$, during the Ottoman Empire ${ }^{40,41}$, and cannot be the main forcing agent behind the permanent open shrub-steppe recorded since the fall of the Crusaders.

\section{Discussion}

Humans are a key component of ecosystem dynamics ${ }^{14,42}$ in and around the site of Akko through an urbanization process that began $\sim 4000$ cal yr BP (Fig. 2), with a background of climate changes and coastal mobility. By adding selection forces to these natural phenomena (climate and coastal mobility), early urbanization gradually changed the expression of ecological processes governing the coastal environmental dynamics before the settlement (Fig. 1a). Plant richness increased in the urban environment (Fig. 1b), due to the highly heterogeneous patchwork of habitats ${ }^{8}$, and the potential co-existence between natural and anthropogenic-favoured species. Whereas proto-urban coastal ecosystems were defined on the basis of variables such as soil, temperature, precipitation and dominant vegetation types (Fig. 1a-d), we show how the urban process (Fig. 2) swiftly generated or amplified a biotic imbalance which increased the biological diversity (Fig. 1b), but reduced the uniqueness and the resilience of the proto-urban ecosystems ${ }^{43}$.

Accelerated population growth since $\sim 4000 \mathrm{BP}^{21}$ (Fig. 2) and unsustainable development generated by socio-economic demands dramatically increased water needs $s^{11,14}$. Higher water uptake from watercourses and water tables, associated with the intentional or unintentional anthropogenic pressures on the fertile alluvial plains of the Na'aman River, the main source of freshwater at Akko, may further explain the expansion of an urban-adapted shrub-steppe. Increased water demand and changes in land use altered the ability of natural reservoirs to fully mitigate the impact of environmental 


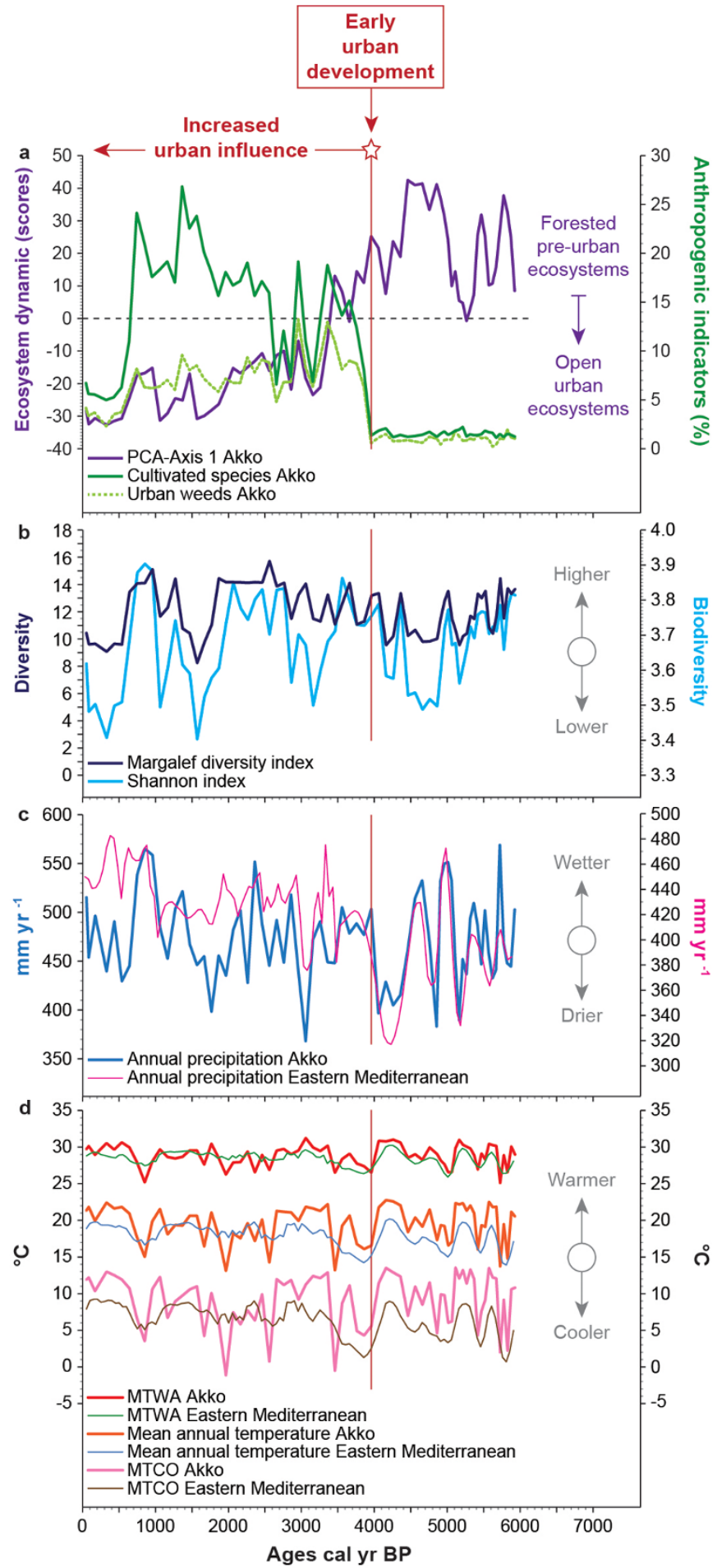

Figure $1 \mid$ A 6000-year environmental reconstruction from Akko.

(a) Pre-urban (positive scores) versus urban-adapted ecosystems (negative scores), with anthropogenic indicators (cultivated species and urban weeds) plotted on a linear age-scale. (b) Diversity indexes (Margalef and Shannon). (c) Annual precipitations reconstructed for Akko and the Eastern Mediterranean. (d) Mean annual temperatures, mean temperature of the coldest month (MTCO) and mean temperature of the warmest month (MTWA) reconstructed for Akko and the Eastern Mediterranean. All the 90\%-confidence intervals are displayed in Supplementary Figs. S4-5.

changes. Two positive feedbacks may have reinforced this process. Firstly, the human-induced fall in free water or vegetated surfaces would have lowered the heat loss due to evaporative cooling, increasing local temperature. Secondly, an increase in solar absorption by

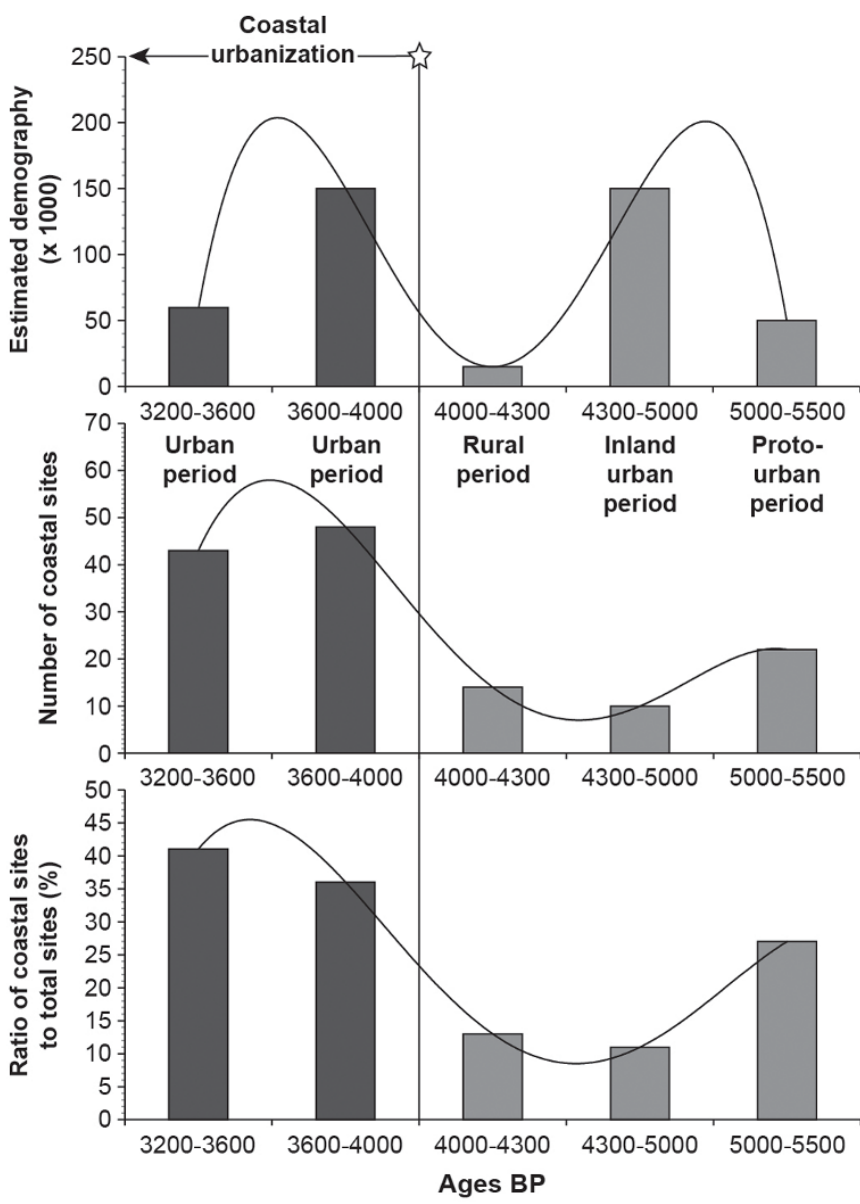

Figure $2 \mid$ Estimated demography for the 5500-3200 BP period in Israel with the number of coastal sites. The ratio coastal versus inland sites gave an historical overview of the urbanization of the littoral. The polynomial curves give global trends for the period 5500-3200 BP. Data were compiled from different sites in Israel ${ }^{45}$.

urban buildings, having higher heat capacities than natural environments and a lower albedo, would also have raised local temperatures (urban heat island) ${ }^{11}$, even if this process was probably limited during the Bronze Age compared to Hellenistic-Roman and later periods. Environmental stress on ecosystems already undermined by human activity (Fig. 1a), produced a specific urban-based vegetation dynamic in the Akko area.

The detailed reconstruction of ecological changes along a ruralurban gradient at the harbour site of Akko provides a unique model to explore the effects of disturbances due to urban dwellers on native vegetation communities since the early rise of cities in the Near East. Land-use changes were likely driven by the first population movements that occupied Akko, but it is only after the foundation of the city that evolving socio-ecological agents, connected with changing human activities and patterns of population densities (Fig. 2) in and around the site, deeply altered the environmental dynamics and natural community structures. This questions the long-held belief of a "golden age" of sustainable early urban development. The same mechanisms that degrade or overexploit the ecosystems nowadays were already at work, even if technologies and agro-innovations were markedly different during the pre-industrial era. Accepting large urban concentrations might need to concede an intrinsic impossibility to produce locally sustainable development. The 4000-year urban history of Akko illustrates the growth of an urban-adapted environment governed by its own ecological rules, based on the loss of particular combinations of populations and species, the fragmentation 
of natural ecosystems and reduced water allocations. Impairment of ecosystem services and loss of biodiversity assets of potential economic significance was the price to pay for these first urban civilizations to ensure a socio-economic development and an expansion of their trade networks. Sustainability was, since the beginning, a utopian goal as landscapes have evolved continuously according to social and economic needs of a particular society at a given moment.

\section{Methods}

Core lithology and chronology. We used biological indicators (pollen grains, fern spores, micro-charcoal fragments, and dinoflagellate cysts) extracted from a continuous core $\left(32^{\circ} 54^{\prime} \mathrm{N}, 35^{\circ} 05^{\prime} \mathrm{E} ;+3\right.$ meter above sea level) drilled on the southern flank of Tel Akko (Supplementary Fig. S1a-b), close to the "old city" of Akko to reconstruct the ecological urban history of the southern Levant. This core was selected from a North-South transect between the foot of the tell and the Na'aman River. The sedimentary deposits $(215 \mathrm{~cm})$ mainly consist of silts and clays, with scarce sand inclusions. The chronology is based on five accelerator mass spectrometry (AMS) radiocarbon $\left({ }^{14} \mathrm{C}\right)$ ages of short-lived terrestrial samples (Table 1). All conventional radiocarbon ages have been calibrated [one and two sigma $(\sigma)$ calendar calibration] using Calib-Rev. 6.0.1 ${ }^{44}$. Compaction corrected deposition rates have been computed between the intercepts of adjacent AMS ${ }^{14} \mathrm{C}$ ages. The age of each sample was calculated by interpolation.

Archaeological and historical data. Archaeological and historical data for urban development derive from 40 years of excavation at the ancient site of Tel Akko (since the work of M. Dothan) and in the "old city", especially the crusader town (since the surveys of the British Mandate Authorities).

Pollen analyses. A total of 70 samples were prepared for pollen analysis using the standard palynological procedure for clay samples. Pollen grains were counted at $\times 400$ and $\times 1000$ magnification using an Olympus microscope. Pollen frequencies (\%) are based on the terrestrial pollen sum excluding local hygrophytes and spores of non-vascular cryptogams. Aquatic taxa frequencies were calculated by adding the local hygrophytes-hydrophytes to the terrestrial pollen sum.

Numerical analyses. Biological data were analysed using Cluster analysis (CA), Kernel density-2D, Matrix, and Principal Components Analysis (PCA). The CA is a technique for hierarchical clustering, finding ranked groupings in multivariate data sets. Here, it is based on pollen-type time-series (presence/absence and abundance). The CA (Supplementary Fig. S2) was used to compute the lengths of branches of a tree, using branches as ecological distances between groups of taxa. CA was computed using Paired group as algorithm and Spearman's Rho ( $\mathrm{r}$ value of the ranks) as similarity measure. The pollen-types from each cluster were summed to create nine pollen-derived ecosystems (Supplementary Table S1).

The ordination of pollen-derived ecosystems was tested using Kernel density-2D with Gaussian as a basis function and three units as radius (Supplementary Fig. S3a$b$ ), and displayed as a two-dimensional plot of the data matrix (percentages; Supplementary Fig. S3c). The Kernel density estimation is a nonparametric technique for density estimation. It represents a generalisation of histogram density estimation with improved statistical properties.

PCA was then performed to test the ordination of samples by assessing major changes in the pollen-derived ecosystems ${ }^{29}$. The main variance is loaded by the PCAAxis1 (Supplementary Table S2). Mediterranean open-forest, Quercus calliprinos woodland and shrub-steppe (natural versus urban-adapted) correspond to the main loadings in the PCA, explaining most of the variance for the PCA-Axis 1 ordination of the data, which accounts for +0.777 of total inertia. Natural ecosystems [Mediterranean open-forest $(+0.84)$, wet meadow steppe $(+0.13)$, Quercus ithaburensis forest $(+0.06)$ and fen trees $(+0.01)]$ are loaded in positive values, whereas negative values correspond to urban-adapted ecosystems [phrygana-batha $(-0.02)$, dry steppe (-0.04), Quercus calliprinos woodland (-0.35) and shrub-steppe $(-0.39)]$. The PCA-Axis 1 scores have been plotted on a linear age-scale to determine the main changes in the Akko core (Fig. 1a).

Climate reconstruction. The climatic data (Supplementary Table S3) used are monthly temperature, precipitation and cloud cover gridded at a step of $0.5^{\circ}$ from 1901 to 2000, provided by the British Atmospheric Data Centre (CRU-TS-3-10) ${ }^{46}$. Pollen diagrams at five sites are considered, Tell Tweini ${ }^{29}{ }$, Bereket ${ }^{47}$, Jableh ${ }^{40}$, Hala Sultan Tekke ${ }^{37}$, and Akko. The closest point of the climatic grid is assigned to each of the five pollen sites. We use a vegetation model (BIOME4) ${ }^{48}$ to estimate the net primary productivity of vegetation in equilibrium with the climate of each of the studied sites. Assuming that there is a relationship between these productivities and the pollen abundances, and that the corresponding residuals have a Gaussian distribution, we estimated the climate scenarios that provide the best fit relationships. This procedure, called model inversion, is solved by a Bayesian approach ${ }^{49}$. Given likelihood comparing model outputs to data and prior parameter models, Markov Chain Monte Carlo (MCMC) technique produces an ensemble of draws from the posterior distribution, from which estimates of the parameters and their associated uncertainties can be made ${ }^{50}$. The parameters are the 36 monthly climatic variables which are summarized into a smaller number of parameters to decrease the complexity of the problem. We used the first four principal components. A large number of iterations $(>10,000)$ are required to analyse the posterior probability distributions (we assume that they are independent). For each pollen assemblage (aggregated into 13 groups compatible with the outputs of BIOME4), and at each iteration, the four parameters are transformed into a 36-size climatic vector which is introduced at the input of BIOME4 (together with the actual $\mathrm{CO}_{2}$ concentration, estimated from ice cores, and modern soil characteristics). A simulation of each vegetation assemblage is obtained and compared to the pollen data. Acceptable scenarios (according to MCMC rules) ${ }^{51}$ are kept to increment the posterior distributions of the climate parameters. Verification is done on 11 modern spectra from the southeast Mediterranean region with modern top core available (four from this study, seven from the European Pollen Database). We have calculated the rootmean-square error (RMSE) and the bias (Supplementary Table S4). It appears that the RMSE is high for the mean temperature of the coldest month and the annual temperature. This is due to a large bias, i.e. a strong underestimation of the winter temperatures, because several tree taxa cannot be unequivocally assigned to cool or warm conifer plant types ${ }^{52}$; then they are assigned to both. The reconstructed variables are corrected by subtracting the bias, and the corrected biases are more acceptable. They are inferior or equal to the $90 \%$ confidence intervals of the reconstructions. That means that, after correction for the respective biases, the modern climate reconstructed by pollen and inverse modelling is not significantly different from the modern climate. The reconstructions for the Holocene (Supplementary Tables S2, S5) are then corrected by the estimated modern climate (top core), and then added to the observed modern climate in Akko or Eastern Mediterranean (Fig. 1c-d, Supplementary Figs S4-5).

1. Childe, G. V. The urban revolution. Town Plann. Rev. 21, 3-17 (1950)

2. Osborne, R. Urban sprawl: what is urbanization and why does it matter? P. Brit Acad. 126, 1-16 (2005)

3. Fall, P. L. \& Falconer, S. E. Seeds of civilization: Bronze Age rural economy and ecology in the Southern Levant. Ann. Assoc. Am. Geogr. 88, 107-125 (1998).

4. Lawler, A. North versus south, Mesopotamian style. Science 312, 1458-1463 (2006).

5. Ur, J. A., Karsgaard, P. \& Oates, J. Early urban development in the Near East. Science 317, 1188 (2007).

6. Ur, J. A. Cycles of civilization in Northern Mesopotamia 4400-2000 BC. J. Archaeol. Res. 18, 387-431 (2010).

7. Menze, B. H. \& Ur, J. A. Mapping patterns of long-term settlement in Northern Mesopotamia at a large scale. Proc. Natl. Acad. Sci. U.S.A. 109, E778-E787 (2012).

8. Hope, D. et al. Socioeconomics drive urban plant diversity. Proc. Natl. Acad. Sci. U.S.A. 100, 8788-8792 (2003).

9. Antrop, M. Sustainable landscapes: contradiction, fiction or utopia? Landscape Urban Plan. 75, 187-197 (2006).

10. Shochat, E., Warren, P. S., Faeth, S. H., McIntyre, N. E. \& Hope, D. From patterns to emerging processes in mechanistic urban ecology. Trends Ecol. Evol. 21, 186-191 (2006)

11. Grimm, N. B. et al. Global change and the ecology of cities. Science 319, 756-760 (2008).

12. Chapin III, F. S. et al. Ecosystem stewardship: sustainability strategies for a rapidly changing planet. Trends Ecol. Evol. 25, 241 (2009).

13. Bateman, I. J. et al. Bringing ecosystem services into economic decision-making: land use in the United Kingdom. Science 341, 45-50 (2013).

14. Alberti, M. et al. Integrating humans into ecology: opportunities and challenges for studying urban ecosystems. BioScience 53, 1169-1179 (2003).

15. Pickett, S. T. A. et al. Beyond urban legends: an emerging framework of urban ecology, as illustrated by the Baltimore ecosystem study. Bioscience 58, 139-150 (2008).

16. Jackson, S. T. \& Hobbs, R. J. Ecological restoration in the light of ecological history. Science 325, 567-569 (2009).

17. Gabbay, S. Coastal Area Management Program, Planning Department. Final Integrated Report (Ministry of the Environment, State of Israel, 2000), http:// www.sviva.gov.il/English/env_topics/marineandcoastalenvironment/ Documents/CoastalAreaManagementProgramme-FinalReport-May2000.pdf (date of access: 2013).

18. United Nations, Department Economic and Social Affairs. World Urbanization Prospects-United Nations 2011, Population Division: the 2011 revision (United Nations, Department Economic and Social Affairs, New York, 2012), http://esa. un.org/unup/pdf/WUP2011_Highlights.pdf (date of access: 2013).

19. Dothan, M. \& Raban, A. The sea gate of ancient Akko. Biblic. Archaeol. 43, 35-39 (1980).

20. Artzy, M. The Carmel Coast during the second part of the Late Bronze Age: a center for Eastern Mediterranean trans-shipping. B. Am. Sch. Oriental. Re. 343, 45-64 (2006)

21. Artzy, M. \& Beeri, R. [Tel Akko] One thousand nights and days - Akko through the ages [Killebrew, A. E. \& Raz-Romeo, V. (eds)] [14-23] (Hecht Museum, Haifa, 2010).

22. Artzy, M. [Return to Tel Akko, its Anchorages, Harbor, and Surroundings] Leon Recanati Institute for Maritime Studies, celebrating 40 years of research, report 37 [Karmon, N. (ed.)] [5-14] (RIMS-University of Haifa, Haifa, 2011).

23. Schilman, B., Bar-Matthews, M., Almogi-Labin, A. \& Luz, B. Global climate instability reflected by Eastern Mediterranean marine records during the Late Holocene. Palaeogeogr. Palaeocl. 176, 157-176 (2001). 
24. Schilman, B., Ayalon, A., Bar-Matthews, M., Kagan, E. J. \& Almogi-Labin, A. SeaLand paleoclimate correlation in the Eastern Mediterranean region during the Late Holocene. Israel J. Earth Sci. 51, 181-190 (2002).

25. Bar-Matthews, M., Ayalon, A., Gilmour, M., Matthews, A. \& Hawkesworth, C. J. Sea-land oxygen isotopic relationships from planktonic foraminifera and speleothems in the Eastern Mediterranean region and their implication for paleorainfall during interglacial intervals. Geochim. Cosmochim. Ac. 67, 3181-3199 (2003)

26. Litt, T., Ohlwein, C., Neumann, F. H., Hense, A. \& Stein, M. Holocene climate variability in the Levant from the Dead Sea pollen record. Quaternary Sci. Rev. 49, 95-105 (2012)

27. Langgut, D., Finkelstein, I. \& Litt, T. Climate and the Late Bronze Collapse: new evidence from the Southern Levant. Tel Aviv 40, 149-175.

28. Bernhardt, C. E., Horton, B. P. \& Stanley, J. D. Nile Delta vegetation response to Holocene climate variability. Geology 40, 615-618 (2012).

29. Kaniewski, D. et al. Middle East coastal ecosystem response to middle-to-late Holocene abrupt climate changes. Proc. Natl. Acad. Sci. U.S.A. 105, 13941-13946 (2008).

30. Sivan, D., Wdowinski, S., Lamback, K., Galili, E. \& Raban, A. Holocene sea-level changes along the Mediterranean coast of Israel, based on archaeological observations and Numerical model. Palaeogeogr. Palaeocl. 167, 101-117 (2001).

31. Sivan, D., Schattner, U., Morhange, C. \& Boaretto, E. What can a sessile mollusk tell about neotectonics? Earth Planet. Sc. Lett. 296, 451-458 (2010).

32. Zviely, D., Kit, E. \& Klein, M. Longshore sand transport estimates along the Mediterranean coast of Israel in the Holocene. Mar Geol 237, 61-73 (2007).

33. Weiss, H. et al. The genesis and collapse of $3^{\text {rd }}$ millennium north Mesopotamian civilization. Science 261, 995-1004 (1993).

34. Staubwasser, M., Sirocko, F., Grootes, P. \& Segl, M. Climate change at the $4.2 \mathrm{ka}$ BP termination of the Indus valley civilization and Holocene south Asian monsoon variability. Geophys. Res. Lett. 30, 1425; DOI: 10.1029/gl016822 (2003).

35. Staubwasser, M. \& Weiss, H. Holocene climate and cultural evolution in late prehistoric-early historic West Asia. Quaternary Res. 66, 372-387 (2006).

36. Kaniewski, D. et al. Late Second-Early First Millennium BC abrupt climate changes in coastal Syria and their possible significance for the history of the Eastern Mediterranean. Quaternary Res. 74, 207-215 (2010).

37. Kaniewski, D. et al. Environmental roots of the Late Bronze Age crisis. PLoS ONE 8, e71004; DOI: 10.1371/journal.pone.0071004 (2013)

38. Zviely, D. et al. Holocene evolution of the Haifa Bay area, Israel, and its influence on ancient tell settlements. The Holocene 16, 849-861 (2006).

39. Stanley, J. D. \& Warne, A. G. Worldwide initiation of Holocene marine deltas by deceleration of sea-level rise. Science 265, 228-231 (1994).

40. Kaniewski, D. et al. The Medieval Climate Anomaly and the Little Ice Age in coastal Syria inferred from pollen-derived palaeoclimatic patterns. Global Planet. Change 78, 178-187 (2011).

41. Kaniewski, D., Van Campo, E. \& Weiss, H. Drought is a recurring challenge in the Middle East. P. Natl. Acad. Sci. USA 109, 3862-3867 (2012).

42. Vitousek, P. M., Mooney, H. A., Lubchenco, J. \& Melillo, J. M. Human domination of earth's ecosystems. Science 277, 494-499 (1997).

43. McKinney, M. L. Urbanization, biodiversity, and conservation. Bioscience 52, 883-890 (2002).

44. Reimer, P. J. et al. IntCal09 and Marine09 radiocarbon age calibration curves, 050,000 years cal BP. Radiocarbon 51, 1111-1150 (2009).

45. Faust, A. \& Ashkenazy, Y. Settlement fluctuations and environmental changes in Israel's coastal plain during the early Bronze Age. Levant 41, 19-39 (2009).
46. Centre for Environmental Data Archival. Climatic Research Unit (CRU), timeseries datasets of variations in climate with variations in other phenomena, Data Entity-Measurement (University of East Anglia, Norwich, 2012), http://badc. nerc.ac.uk/view/badc.nerc.ac.uk_ATOM_dataent_1256223773328276 (date of access: 2013).

47. Kaniewski, D., Paulissen, E., De Laet, V., Dossche, K. \& Waelkens, M. A highresolution Late Holocene landscape ecological history inferred from an intramontane basin in the Western Taurus Mountains, Turkey. Quaternary Sci. Rev. 26, 2201-2218 (2007).

48. Kaplan, J. O. et al. Climate change and arctic ecosystems: 2 . Modeling, paleodatamodel comparisons, and future projections. J. Geophys. Res. 108, 8171 (2003).

49. Guiot, J., Wu, H., Garreta, V., Hatté, C. \& Magny M. A few prospective ideas on climate reconstruction: from a statistical single proxy approach towards a multiproxy and dynamical approach. Clim. Past 5, 571-583 (2009).

50. Gilks, W., Richardson, S. \& Spiegelhalter, D. Markov Chain Monte Carlo in practice [Gilks, W., Richardson, S. \& Spiegelhalter, D. (eds)] [1-512] (Chapman and Hall, Boca Raton, 1996).

51. Gelman, A., Carlin, J., Stern, H. \& Rubin, D. Bayesian Data Analysis [Gelman, A., Carlin, J., Stern, H. \& Rubin, D. (eds)] [1-696] (Chapman and Hall, Boca Raton, 2003).

52. Tarasov, P. E. et al. A method to determine warm and cool steppe biomes from pollen data; application to the Mediterranean and Kazakhstan regions. J. Quaternary Sci. 13, 335-344 (1998).

\section{Acknowledgments}

Support was provided by the Institut Universitaire de France, CLIMSORIENT and Geoarchaeology of ancient Black Sea harbours programs, the Université Paul Sabatier, the Mistrals-ENVIMED-GEOISRAEL program, and by the Hatter Laboratory, Recananti Institute for Maritime Studies, University of Haifa. This work is also a contribution to the Labex OT-Med (ANR-11-LABEX-0061) funded by the «Investissements d'Avenir», French Government program of the French National Research Agency (ANR) through the A*Midex project (ANR-11-IDEX-0001-02).

\section{Author contributions}

D.K., E.V.C., C.M. and M.A. had the idea for the research. D.K. and E.V.C. performed the research, undertook the data collection, and led the statistical analysis. J.G. led the climate reconstruction. D.K., E.V.C., C.M., J.G., D.Z., I.S., T.O. and M.A. contributed to the analysis and interpretation of the results. D.K. wrote the first draft of the paper and all authors contributed to writing the manuscript.

\section{Additional information}

Supplementary information accompanies this paper at http://www.nature.com/ scientificreports

Competing financial interests: The authors declare no competing financial interests.

How to cite this article: Kaniewski, D. et al. Early urban impact on Mediterranean coastal environments. Sci. Rep. 3, 3540; DOI:10.1038/srep03540 (2013).

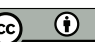

This work is licensed under a Creative Commons Attribution 3.0 Unported license. To view a copy of this license, visit http://creativecommons.org/licenses/by/3.0 